\title{
10 Commentary
}

\section{The restorative archeology of knowledge about the role of women in the history of the UN - Theoretical implications for international relations}

\author{
Rebecca Adami, Dan Plesch and Amitav Acharya
}

The role of women in the history of the United Nations should be seen in the context of emerging and re-emerging debates in International History and International Relations. A cartoon of the problem characterizes international history as lacking in theoretical self-consciousness and fearful of the contamination of contemporary relevance to policy and social practice. International Relations on the other hand is beset by increasingly reified theories distant from empiricism. ${ }^{1}$ The original term of Michel Foucault, Archeology, is a form of discourse analysis to analyze continuities and discontinuities of thought. ${ }^{2}$ The term also creates thoughts of the historical school of study rather than of political science. Thus, the term bridges disciplines. The word restorative carries both the archaeological meaning of an object for study and appreciation, but also a sense of buried treasure to illuminate and empower the contemporary world. At the present time politics contains both efforts to advance human rights - not least women's rights and the development of organized global humanity and also a profound reaction towards patriarchal tribalism. The works in this volume revisit the foundational period of global organizations - specifically the United Nations. They demonstrate empirically and theorize a far richer reality of global feminisms in this foundational period than has previously been recognized either by feminist scholarship or by traditional historical and international relations discourses.

By unearthing the hidden history of women in shaping human rights internationally through the UN, we gain important insights into how women from the Global South - although in minority in UN bodies and in their own delegations - not only historically sat "at the table" but were architects of "the table" at which Member States now sit in the United Nations today. The inclusion of gender equality in the UN Charter, of women's rights in the UDHR, the adoption of the first two international conventions on the rights in marriage and of political rights of women, the adoption of the CEDAW, and more recently of the Resolution 1325 in the Security Council on the participation of women in peace constitute a hegemonic norm on gender equality for international relations and broader global society. The evidence in this volume fills the absence of recognition of the intellectual thought of women of colour in international politics and

DOI: $10.4324 / 9781003036708-10$ 
in the making of world politics through the United Nations, countering the false impression in the history of IR that Patricia Owens has argued against, namely that women in the history of world politics did not think seriously about international politics. ${ }^{3}$ The hegemonic norm on gender equality that exists today was made possible through the work of non-Western feminists at the founding of the UN in the post-war years. ${ }^{4}$ Torild Skard, a pioneer in addressing the gap in earlier research on the role of women from Latin America at the founding of the UN, recalls that while her own mother Åse Gruda Skard took an "intermediate" position on advancing women's rights in 1945 together with the Chinese delegate Wu Yi-fang, the Latin American women delegates headed by Bertha Lutz made sure that gender equality was included in the Charter. ${ }^{5}$ The Latin American feminists had experience of international politics and negotiations from the Pan-American conferences, and they were disappointed in the Dumbarton Oaks agreement for not having included women's human rights and anti-racism. ${ }^{6}$ The women from India and Pakistan who took part in deliberations concerning human rights in the UDHR were prominent political leaders active in anti-colonial struggles and the UN, as Khushi notes, was not their first appearance internationally. The role of international feminism during the early Cold War period has been simplified in earlier accounts as mired in dichotomies obscuring links between welfarism and feminism on the one hand and internationalism and feminism on the other. ${ }^{7}$ By advancing the concept of "international welfare feminism" Adami argues that the role of Southern women delegates in the UN who advanced women's economic rights should not be conceptualized as caught in East-West ideologies but rather connected to a feminist international agency against patriarchal and colonial structures that limited women's rights. Nationalist ideologies have come to overshadow these vital narratives on women's rights and freedoms. The conceptualization of "international welfare feminism" further questions the assumption that Western feminism was internationalized through the UN; the push for economic and social rights by Southern feminists, as through the Indian National Trade Union Congress and elsewhere, speak about agency in international relations in a new inspiring way. The scope of agency in International Relations, as Amitav Acharya eloquently demonstrates in earlier work, needs to continue to be recast; and this is where the hidden historical narrative of feminist agency from the Global South in the UN provide us with contestations of the dominant narrative which opens space for analyzing the diverse foundations of the global order. ${ }^{8}$ These women delegates were not, as we have seen, passive recipients of Western values and norms but rather had the agency to bring about change. ${ }^{9}$

The historical accounts of non-Western women in the UN provide a case for expanding Amitav's earlier conception of agency as not only including male agency from the Global South in the post-war period who used the UN to strengthen the voice of newly independent states but non-Western women politicians as well. Roland Burke ${ }^{10}$ discloses that among the earliest travelling advisory seminars on human rights of the UN, assembling in Bangkok, Bogotá Addis Ababa, and Lomé, were those devoted to questions of women's freedoms and welfare. International feminism in the Cold War years was, as noticeable 
from the angles studied in this volume, marked by anti-colonialism and anti-patriarchal intellectual thought of women. The Peruvian feminist Carmela Aguilar with her Incan heritage argued for the supremacy of the UDHR over prejudice and tradition in order not to deprive women of their fundamental rights. ${ }^{11}$ Aoife O'Donoghue and Adam Rowe in this volume demonstrate how the post-colonial context in the 1970s (the New International Economic Order, the Non-Alignment Movement, and the Group 77) meant an increasingly significant voice in international conferences ${ }^{12}$ in their exploration of the first inter-governmental global conference to focus on women; the Mexico Conference in 1975. This shift in power led to a heightened concern in the mid-1980s regarding Western moral imperialism when Ethiopian rights activist Berhane Ras-Work-representing the Inter-African Committee on Traditional Practices Affecting the Health of Women and Children - crafted with Save the Children a proposal to eradicate harmful traditional practices that she refused to conflate with cultural or religious practices but as indicative of a global patriarchal structure. ${ }^{13}$ This volume hence sets the last 70 decades of the UN in a different, and inspiring light, by giving long-sought after kudos to the women architects of gender equality in key UN resolutions, declarations, and conventions. Ellen Chesler provides historical context to the drafting of DEDAW and CEDAW crediting two women as principal architects of the declaration and the convention respectively, Annie Jiagge (Ghana) and Leticia Shahani (the Philippines). As Chesler notes in her conclusion; "the all too common characterization of women's rights as a western invention, imposed on innocents elsewhere in the world, is not only wrong but also insulting." 14 One would not but agree as the history of focal UN documents, treaties, and conventions on women's human rights in this volume unfold as fundamentally other than western imperialism. Cornelia Weiss continues this unfolding of UN history into a new millennium as she unearths the role of Namibia behind the first draft for the Security Council Resolution 1325 and the role of women leaders Selma Ndeyapo Ashipala-Musavyi, the Deputy Permanent Representative of Namibia, and First Secretary Aina Liyambo. ${ }^{15}$

The agency of women in International Relations, explored in this volume, in how they brought about change in key UN documents, was possible through the representation of feminists from the Global South at the table. As the authors of these chapters remind us, women have constituted a minority in International Relations and had to form a caucus to achieve change (see intro note on the Charter, chap 1 and 2 on the women and the Charter, chap 4 on the CSW, chap 9 on female Permanent Representatives in 1990s). ${ }^{16}$

\section{Varieties of agency}

Agency refers to the will and capacity to create or contribute. One of the important insights of the emerging literature on global governance and multilateralism is what Acharya has called the "pluralization of agency". Agency should not be equated with states, or organized non-state actors, but also individual women and men. While these individuals may be working for, or associated with 
governments, inter-governmental organizations or NGOs, they do leave their own distinctive mark on international agreements and institutions which may not necessarily reflect the positions of the organizations they work for. In this volume, a number of outstanding examples of such acts of agency by women have been discussed.

In addition, agency is pluralized in a variety of ways: broadly stated, these include (1) Agency through dissent and resistance to mainstream ideas and rules of the day, championed by influential figures or governments they represent, and the offering of alternative ideas and norms; (2) Agency of weak states and their representatives, as opposed to the agency of powerful nations and their representatives; (3) Agency by proposing new ideas and norms even if their backers may not have the power to propagate and enforce them; and (4) Agency that focuses not on location of the agent when they create or modify the norm, but the location of their origins or where their ideas were initially formed.

This volume offers multiple illustrations of such agency by women in the building of the UN system. One example of the first form of agency is the challenge made by Indian representative to the UN Commission on Human Rights, Hansa Mehta, to the Chair of the UDHR drafting Committee, Eleanor Roosevelt, which led to the language of the UDHR being changed from "all men are created equal" to "all humans". ${ }^{17}$ Another case is how Bertha Lutz (Brazil) argued for the importance of women to be able to hold the same positions as men in the UN-system, through Article 8 in the UN Charter in opposition to Virginia Gildersleeve (US) who thought women should not "ask for too much."18

The second form of agency is exemplified by how Annie Jiagge (Ghana) and Leticia Shahani (the Philippines) wrote key drafts of the initial articles on women's rights in the DEDAW and the CEDAW while representing weaker states in comparison to other Member States represented in the CSW. ${ }^{19}$ Other foundational role models are Selma Ndeyapo Ashipala-Musavyi (Namibia) and Aina Liyambo (Namibia) who played pivotal roles in international legislation and norm-setting on gender equality through UN Resolution 1235 while Namibia was UN Security Council member only 1999-2000 in contrast to the much more powerful five permanent members to the Council (China, US, Russia, France, and the UK) and to the rather better publicized work of US funded NGOs. ${ }^{20}$

The third form of agency can be illustrated through the articulation of gender equality and substantive rights by the first women representatives of independent India; Vijaya Lakshmi Pandit, Hansa Mehta, Shareefah Hamid Ali, and Lakshmi Menon who advocated human rights without discrimination based on their personal convictions that the UN should develop international legal machinery to uphold respect for human rights in newly independent Member States and former colonial powers alike. ${ }^{21}$ Another example of the third form of agency can be found in the work against traditional abuses of women by Begum Rana Liaquat Ali Khan (Pakistan), Badia Afnan (Iraq) and Aziza Hussein (Egypt) who questioned dominant patriarchal narratives that denied women rights in the countries they represented while advocating for progressive feminism in the UN as a way to influence national policies and legislation through international pressure. ${ }^{22}$ 
Lastly, the fourth form of agency is epitomized by the international advocacy for gender equality that Minerva Bernardino (the Dominican Republic) accomplished with the first international Convention on the Political Rights of Women approved in 1952 by the UN General Assembly under her leadership as chair of CSW (preceding the CEDAW by 27 years). Bernardino was born in the Dominican Republic but lived in Washington and shifted in her UN engagement between acting in the capacity of delegate representative and as Chair to the Inter American Commission on Women, to avoid the limitations and constraints that came from representing an autocracy at the UN. ${ }^{23}$ Leticia Shahani (the Philippines) by her crucial influence on the CEDAW is another example of the fourth form of agency. Shahani had moved to and was living in the US with her husband, a Karachi born intellectual, while still representing the Philippines which was also part of the powerful alliance of the Group of 77 non-aligned Nations (G77) at the $\mathrm{UN}{ }^{24}$

The women named in this volume may be seen as not representative of women around the globe while they constituted a rather privileged section of societies through their official capacity, and others through their affiliation with international NGOs. The ambition of international diplomacy work through the UN that this volume speaks of, nevertheless, is to generate local change through international norm-setting on women's human rights. Re-thinking IR not only distinguishes these important forms of agency newly restored; but conceptualizes political space beyond a global/local divide in how people act for change. "[A] political space does not emerge solely between individuals who are equal in formal and legal terms, but (...) equal in dignity though lacking in rights." ${ }^{25}$ The limitations with interpreting the actions of individual's in the history of the UN through solely their formal representation, their country of origin, their gender, and other social categorizations concern the ways in which identity politics obscures more relational, contextual and complex reasons for igniting change. More research is needed on the many local actors and individuals who have advocated human rights on occasion at a global level through their personal commitments based on their rooted experiences.

Acharya engages in his work on agency with individual actors outside the UN system who bring together all four types of agency, for example Wangari Maathai (1940-2011). She was the winner of the 2004 Noble Peace Prize for her work in sustainable development that led to the Greenbelt movement that she had founded in 1977. Maathi was born in poverty and became a dissenter against her own government. Her advocacy of reforestation led to threats from the Kenyan government to send her to prison. She lacked material resources to launch her movement but found support from Kenyan people and some members of the international community.

Some Western analysts think that while the ideas coming from scholars and practitioners in the Global South such as Maathai which lead to the creation of new norms and institutions are possible only because they were trained in Western academic institutions, and/or worked for international institutions based in the West and led by Westerners. 
Such denial of Global South agency is based on flawed logic. Maathai was trained in the US (University of Pittsburg) and did receive political backing and financial resources from countries such as Canada. Nonetheless, her ideas and campaigns were deeply rooted in her childhood experience in Kenya. Maathai developed the ideas of planting millions of trees to rejuvenate the forests around Nairobi lost to urbanization as a solution to Kenyan women's lack of rights. These women were facing severe financial and social hardship because of their inability to find supplies of firewood due to deforestation. Hence Maathai reasoned that bringing the trees back would improve women's livelihood and the society as a whole:

The trees would provide a supply of wood that would allow women to cook nutritious foods. They would also have the wood for fencing and fodder for cattle and goats. The trees would offer shade for humans and animals, protect watersheds and bind the soil, and, if they were food trees, provide food. They would also heal the land by bringing back birds and small animals and regenerate the vitality of the earth. ${ }^{26}$

This Maathai's work demonstrated "how traditional survival techniques such as intercropping and agroforestry can be inexpensively resurrected through women's special skills." 27

Notwithstanding their Western training or workplace, multilateralists as Maathai from the Global South act from the script that was originally developed in the place of their upbringing. The ideas of human development and human security were proposed by Mahbub ul Haq and Amartya Sen, with Haq's wife, Dr Khadija Haq, a noted development economist in her own right. While these ideas were articulated through their association with the United Nations Development Program (UNDP), there is no question that they were rooted in their place of origins, South Asia, and the experience of famines and violence of the partition of the sub-continent.

The authors' skillful archaeological work restores to glory the work of women of prior generations from the Global South that may be inspirational to countless of their descendents still experiencing the world in a manner that Sator describes with such telling precision.

\section{Notes}

1 see Amitav Acharya and Dan Plesch, "The United Nations: Managing and Reshaping a Changing World Order" (2020 Annual Meeting - UN@75: The Future of Partnership and Multilaterism, London Metropolitan University, UK, 2020).

2 Michael Foucault, The Archeology of Knowledge, trans. A.M. Sheridan Smith (London : New York: Routledge, 2002).

3 See Singh Rathore, 'Excavating Hidden Histories', this volume, ch. 3.

4 See Dietrichson and Sator 'The Latin American Women', this volume, ch. 2.

5 See Skard 'Learning journey for a feminist', this volume, Introductory note.

6 See Marino 'From Women's Rights to Human Rights', this volume, ch. 1.

7 See Adami 'International Welfare Feminism', this volume, ch. 4. 
8 Amitav Acharya, Constructing Global Order: Agency and Change in World Politics (New York: Cambridge University Press, 2018).

9 Acharya.

10 See Burke 'Universal Human Rights for Women', this volume, ch. 5.

11 Ibid.

12 See O'Donoghue and Rowe 'Feminism, Global Inequality and the 1975 Mexico City Conference', this volume, ch. 6.

13 See Lindkvist 'Where Children's Rights Ever a Feminist Project?', this volume, ch. 8.

14 Chesler 'Who Wrote CEDAW?', this volume, ch. 7, p.

15 See Weiss 'Creating UNSCR 1325', this volume, ch. 9.

16 See Skard 'Learning journey for a feminist', this volume, Introductory note; Marino 'From Women's Rights to Human Rights', this volume, ch. 1; Dietrichson and Sator 'The Latin American Women', this volume, ch. 2; Adami 'International Welfare Feminism', this volume, ch. 4; and Weiss 'Creating the UNSCR 1325', this volume, ch. 9.

17 Rebecca Adami, Women and the Universal Declaration of Human Rights (New York \& London: Routledge, 2019). See also Khushi Rathore,'Excavating Hidden Histories', this volume, ch. 3 .

18 Adami; Katherine Marino, Feminism for the Americas: The Making of an International Human Rights Movement (Chapel Hill \& London: The University of North Carolina Press, 2019). See also Dietrich Luhr and Sator'The Latin American Women', this volume, ch. 2.

19 See Chesler 'Who Wrote CEDAW', this volume, ch. 7.

20 See Weiss 'Creating the UNSCR 1325', this volume, ch. 9.

21 See Khushi Rathore 'Excavating Hidden Histories', this volume, ch. 3.

22 See Burke 'Universal Human Rights for Women', this volume, ch. 5.

23 Adami, Women and the Universal Declaration of Human Rights; Marino, Feminism for the Americas: The Making of an International Human Rights Movement; Ellen DuBois and Lauren Derby, "The Strange Case of Minerva Bernardino: Pan American and United Nations Women's Right Activist," Women's Studies International Forum 32, no. 1 (January 2009): 43-50, https://doi.org/10.1016/j.wsif.2009.01.005. See Skard 'Learning journey for a feminist', this volume, introductory note; Marino 'From Women's Rights to Human Rights', this volume, ch. 1; Dietrich Luhr and Sator 'The Latin American Women', this volume, ch. 2; Burke 'Universal Human Rights for Women', this volume, ch. 5.

24 See Chesler 'Who Wrote CEDAW?', this volume, ch. 7.

25 Rebecca Adami, "Human Rights For More Than One Voice: Re-Thinking Political Space Beyond the Local/Global Divide," Ethics \& Global Politics 7, no. 4 (2014): 176.

26 Wangari Maathai, cited in Amitav Acharya, "'Idea-shift': How Ideas From the Rest are Reshaping Global Order," Third World Quarterly, vol. 37, no. 7 (2016), p. 1166.

27 Wangari Maathai, cited in Acharya, "Idea-shift"”. p. 1166.

\section{Bibliography}

Acharya, Amitav. Constructing Global Order: Agency and Change in World Politics.

New York: Cambridge University Press, 2018.

Acharya, Amitav, and Dan Plesch. "The United Nations: Managing and Reshaping a Changing World Order." UK: London Metropolitan University, 2020.

Adami, Rebecca. "Human Rights For More Than One Voice: Re-Thinking Political Space Beyond the Local/Global Divide." Ethics \& Global Politics 7, no. 4 (2014): 163-180.

Adami, Rebecca. Women and the Universal Declaration of Human Rights. New York \& London: Routledge, 2019. 


\section{Rebecca Adami, Dan Plesch and Amitav Acharya}

DuBois, Ellen, and Lauren Derby. "The Strange Case of Minerva Bernardino: Pan American and United Nations Women's Right Activist." Women's Studies International Forum 32, no. 1 (January 2009): 43-50. https://doi.org/10.1016/j.wsif.2009.01.005.

Foucault, Michael. The Archeoslogy of Knowledge. Translated by A.M. Sheridan Smith. London: New York: Routledge, 2002.

Marino, Katherine. Feminism for the Americas: The Making of an International Human Rights Movement. Chapel Hill \& London: The University of North Carolina Press, 2019. 